Table 3 Miscellaneous Ostraca with "Makkedah" ............. . xxxv

Table 4 The Dossier of Wheat Flour . . . . . . . . . . . . . . . xxxvi

Table 543 Idumean Ostraca Dated according to Macedonian Rulers . . . . . . . xxxviii

Dossiers

Table $6 \quad$ Baalrim at a Glance $(\mathrm{A} 1) \ldots \ldots \ldots \ldots$

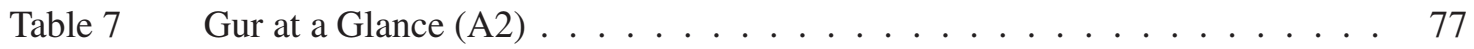

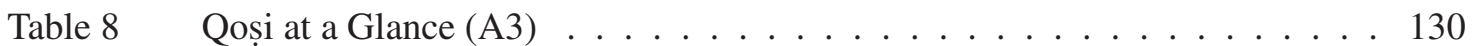

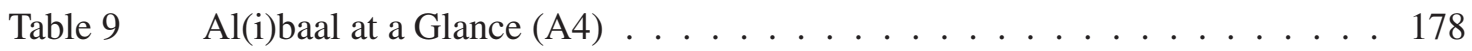

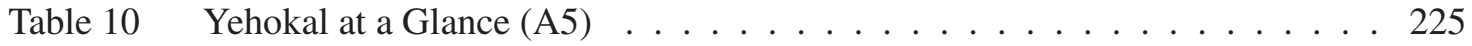

Table 11 Miscellaneous Clans at a Glance (A6) . . . . . . . . . . . . . . . . . . . . . . . . . . . . . . . . .

Table $12 \quad \mathrm{Hal}(\mathrm{a})$ fat-Baalghayr at a Glance $(\mathrm{A} 7) \ldots \ldots \ldots \ldots$

Table $13 \quad$ Samitu at a Glance $(\mathrm{A} 8) \ldots \ldots \ldots \ldots \ldots$. . . . . . . . . . . . . . . . . . . . .

Table 14 Qoskahel at a Glance (A9) . . . . . . . . . . . . . . . . . 400

Table 15 Saadel at a Glance $(\mathrm{A} 10) \ldots \ldots \ldots$. . . . . . . . . . . . 433

\title{
Figures
}

Introduction

Figure $1 \quad$ Map of Provenanced Aramaic Ostraca _. . . . . . . . . . . . . . xl

Figure 2 Lenny Wolfe's Pedigree . . . . . . . . . . . . . . . . xli

Figure 3 Dispersion of 913 Published Aramaic Ostraca Photos in 14 Publications . . . xlii

Figure 4 List of 2,004 Ostraca from 30 Different Collections . . . . . . . . . . . . . xlii

Figure 5 An Ostracon Acquired in Rafiah (ISAP2034) . . . . . . . . . . . . . xliii

Figure 6 el-Kom 8 and an Idumean Ostracon Compared . . . . . . . . . . . . . xliii

Figure 7 Maresha 6 (A38.9) and an Idumean Ostracon Compared . . . . . . . . . . . xliv

Figure 8 Four Grain Chits from the David Sofer Collection . . . . . . . . . . . xliv

Figure 9 Three Chits "To the Port" $($ Mahoza $) \ldots \ldots \ldots$. . . . . . . . . . . . xlv

Figure 10 Transporting the Goods in the Idumean Ostraca . . . . . . . . . . . . . . xlv

Figure $11 \quad$ Unfaux $($ ISAP1161) . . . . . . . . . . . . . . . . . xlvi

Figure $12 \quad$ Unfaux $($ ISAP1162) . . . . . . . . . . . . . . . . . . xlvi

Figure 13 An Apprentice's Writing Exercise or a Forgery? (ISAP648/1381) . . . . . . xlvi

Figure 14 Unintelligible Fake (ISAP1213) . . . . . . . . . . . . . . . . . xlvi

Figure 15 Inscription on a Jar Handle? (ISAP1214) . . . . . . . . . . . . . . . . xlvi

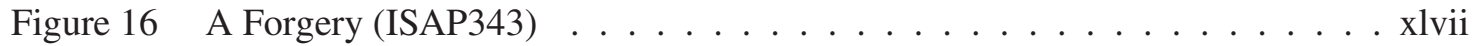

Figure 17 A Forgery $($ ISAP341) . . . . . . . . . . . . . xlvii

Figure 18 Unintelligible List of Names (ISAP342) . . . . . . . . . . . . . . . . . xlvii

Figure 19 Authentic List of Names (ISAP1958) . . . . . . . . . . . . . . . . xlvii

Figure 20 Unintelligible Script (ISAP499) . . . . . . . . . . . . . . . . . xlvii

Figure 21 Two-sided Scribal Exercise (ISAP2409) . . . . . . . . . . . . . . . . . . xlviii

Figure 22 Two-sided Scribal Exercise (ISAP2440) . . . . . . . . . . . . . . xlviii

Figure 23 Exercise in Circular Strokes (ISAP315) . . . . . . . . . . . . . . xlviii

Figure 24 Exercise in Random Strokes (ISAP852) . . . . . . . . . . . . . . . . xlviii

Figure 25 Exercise in Horizontal and Vertical Strokes (ISAP146) . . . . . . . . . . . xlviii

Figure 26 Compact Diversity of Strokes (ISAP2442) . . . . . . . . . . . . . . xlix

Figure 27 Scattered Semicircles (ISAP659) . . . . . . . . . . . . . xlix 
Figure 28 Compact Semicircles (ISAP1322) . . . . . . . . . . . . . . . xlix

Figure 29 Two-sided Scribal Exercises at Elephantine (X31 and 197) . . . . . . . . . 1

Figure 30 Exercise in Random Strokes at Elephantine . . . . . . . . . . . . . . . . . 1

Figure 31 An Abecedary (ISAP1631) . . . . . . . . . . . . . . . . . . . . 1

Figure 32 Un faux authentifié (A39.4 [ISAP1218]) . . . . . . . . . . . . . li

Figure 33 Sample Commodity Chit with Ruler in Year Date (A33.8 [ISAP1546]) . . $\quad$ li

Figure 34 Sample Clan Commodity Chit (A4.14 [ISAP1235]) . . . . . . . . . . . li

Figure 35 Sample Commodity Chit with Verb (A9.9 [ISAP1944]) . . . . . . . . . . lii

Figure 36 Sample Commodity Chit with Date at End (A47.2 [ISAP709]) . . . . . . . lii

Figure 37 Terse Commodity Chit (A131.1 [ISAP73]) . . . . . . . . . . . . lii

Figure 38 Sample Unabbreviated Commodity Chit (A1.35 [ISAP1718]) . . . . . . . lii

Figure 39 Sample Land Description (H3.1 [ISAP1966] . . . . . . . . . . . . . . . liii

Figure 40 Land Description with Temples and Tombs (H1.1 [ISAP1283]) . . . . . . liii

Figure 41 Sample Workers Text (D3.6 [ISAP260]) . . . . . . . . . . . . . liii

Genealogical Charts

Figure 42a Four Generations of the Clan of Baalrim . . . . . . . . . . . . . 4

Figure $42 \mathrm{~b}$ The Third Generation of the Clan of Baalrim . . . . . . . . . . . . . 4

Figure 43 Five Generations of the Clan of Gur . . . . . . . . . . . . . . . . 76

Figure 44 Five Generations of the Clan of Qoși . . . . . . . . . . . . . . . . . . . . 129

Figure 45 Three Generations of the Clan of Al(i)baal . . . . . . . . . . . . . . . 177

Figure 46a Four Generations of the Clan of Yehokal (first reconstruction) . . . . . . . 223

Figure 46b Five Generations of the Clan of Yehokal (second reconstruction) . . . . . . 224

Figure 47 Comparing Generations of the Five Clans . . . . . . . . . . . . . . . 248

Comparative Clan Profiles

Figure 48 Comparison of Dating Profiles for 5 Clans . . . . . . . . . . . . . . . 249

Figure 49 Comparison of Commodity Profiles for 5 Clans . . . . . . . . . . . . . . 249

Figure 50 Comparison of Payee Profiles for 5 Clans . . . . . . . . . . . . . . 250

Figure 51 Comparison of Agent Profiles for 5 Clans . . . . . . . . . . . . . . . 250

Figure 52 Summary of Clan Profiles . . . . . . . . . . . . . 251

\section{Comparative List of Entries}

Listed by TAO Number . . . . . . . . . . . . . . . . . . . . . . . . . . . . . . . 469

Listed by ISAP Number . . . . . . . . . . . . . . . . . . . . . . . 471

\section{Supplementary Material on CD}

Complete Table of Contents for TAO A-K

Complete ISAP-TAO Equivalency Chart

Commodity Chit Dossiers Listed by Payer Name for A1-281

KWICs

Personal Names KWIC

Word KWIC

Months KWIC 